\title{
The Dutch Grey Market
}

\section{Luc Renneboog • Christophe Spaenjers}

(C) The Author(s) 2010. This article is published with open access at Springerlink.com

\begin{abstract}
When-issued trading concerns transactions in securities that have not yet been issued. This paper investigates the Dutch "grey market" for when-issued shares prior to stock splits, using a unique hand-collected data set. Market makers are more likely to set up a when-issued market when the underlying firm is larger, the relative trading volume of the stock is higher, and the stock return is less volatile. The whenissued securities trade at a small premium over the regular shares during the weeks prior to the stock split, but this when-issued premium disappears in the last days of trading.
\end{abstract}

Keywords Capital markets · Law of one price - Stock splits ·

When-issued trading

\section{JEL Classification $\mathrm{G} 1 \cdot \mathrm{G} 2$}

\section{Introduction}

A "grey market" is a trading place that is not officially endorsed. In the context of securities, the term often describes an informal market in which brokers and investors write contracts for the purchase and sale of equities (or bonds) that have yet to be issued. Trading happens on a when-issued basis, meaning that the actual delivery and settlement will take place only if and when the securities are issued. In the U.S., when-issued trading has existed at least since the 1940s (Loss and Vernon 1945).

L. Renneboog · C. Spaenjers ( $₫)$

CentER, Tilburg University, P. O. Box 90153, 5000 LE Tilburg, The Netherlands

e-mail: C.Spaenjers@uvt.nl

L. Renneboog

e-mail: Luc.Renneboog@uvt.nl 
Although there are international differences, when-issued trading typically occurs in the run-up to a stock split. Investors can buy and sell forward contracts on the postsplit shares in the weeks before the the effective date of the split. During this period, the when-issued shares thus trade parallel to the old shares. Choi and Strong (1983) were the first to observe that when-issued securities seem to trade at a premium over regular shares. This apparent violation of the law of one price has triggered a modest wave of research on the pricing of when-issued securities. Lamoureux and Wansley (1989) and Brooks and Chiou (1995) argue that a number of empirical issues can complicate correct measurement of the premium; Nayar and Rozeff (2001) show that the premium may be due to the inconvenience of trading in the unsplit shares after the record date. However, these studies solely employ U.S. data, and it is unclear whether when-issued securities also trade at a premium in other countries.

This paper examines the grey market in the Netherlands, historically also called a "phantom market" because of the lack of transparency on both the players and the price formation in this market. The Amsterdam Stock Exchange imposed certain disclosure requirements on when-issued trading in 1989, but banned it at the end of 1998 . We therefore look into the when-issued activity over these ten years, when a buoyant grey market prior to stock splits existed. ${ }^{1}$ Based on a novel, hand-collected data set of when-issued prices, we reach the following conclusions:

(1) Over our time frame, a when-issued market is organized prior to almost half of the stock splits that take place on the Amsterdam Stock Exchange, implying that there is a clear demand for such grey markets. In most cases, trading starts shortly after the official announcement of the split.

(2) Stock splits are more likely to be preceded by when-issued trading when the underlying firm is larger, the relative trading volume of the stock is higher, and the stock return is less volatile. This supports the hypothesis that market makers will set up a when-issued market when the expected number of transactions is large and the expected costs are low.

(3) When-issued securities trade at a small, but economically significant premium prior to a stock split. On the basis of when-issued and regular share closing prices, we calculate premiums of $0.50-1.50 \%$ on nearly all of the 50 trading days leading up to the stock split. Only in the last days of when-issued trading the premium disappears.

(4) When we correct the premium for the time value of money, it disappears until roughly 20 trading days before the split. After this date, and until a week prior to the effective date, the average premium is about $0.60 \%$. Again, there is no premium in the last days before the stock split. Moreover, also long before the stock split no premium exists after adjustment for the time value of money.

Unfortunately, there is no information available on the type of investors or the volumes traded in the Dutch grey market. Therefore, even though we confirm

\footnotetext{
${ }^{1}$ We do not investigate the when-issued trading that took place prior to IPOs, because of the small number of observations. The research on such trading in other European countries has focused on the informational value of pre-IPO prices (Löffler et al. 2005), and the use of grey market prices (Cornelli et al. 2006) or retail purchases in the when-issued market (Dorn 2009) as proxies for investor sentiment.
} 
that there is a demand for when-issued securities and we look into which factors make the emergence of a grey market more likely, we do not directly address the impact of when-issued trading on overall market functioning or economic welfare.

Nevertheless, this paper contributes to the existing literature in at least two ways. First, this is the initial study to investigate the Dutch grey market prior to stock splits. As noted before, the research on such when-issued trading has been an exclusively U.S. preoccupation. This paper shows that the when-issued premium is a more global phenomenon, even though the premium we calculate is lower than the one found in previous studies, such as Brooks and Chiou (1995) and Nayar and Rozeff (2001). Second, our analysis offers additional insights in the workings of whenissued markets. For example, we explicitly analyze when market makers deem it attractive to set up a grey market prior to stock splits, and find results in support of Nayar and Rozeff (2001). We also examine the time pattern in the when-issued premium over a longer period than previous research. For example, Choi and Strong (1983) and Brooks and Chiou (1995) both start their analysis twenty days before the ex-date.

The remainder of this paper is structured as follows. The recent history of the Dutch grey market is outlined in Sect. 2. Section 3 reviews the relevant literature on whenissued trading prior to stock splits. Our data set is described in Sect. 4, while Sect. 5 gives an overview of the empirical results. Section 6 concludes.

\section{When-Issued Equity Trading in The Netherlands}

A Dutch newspaper once likened when-issued trading-officially called "as-if-whenissued" trading in the Netherlands-prior to stock splits and IPOs to "shopping before the store has opened" (De Volkskrant 2000). Up until 1989, there were no rules for the Dutch grey market, leading to concerns about the price formation and the legal validity of the transactions in this market. At the end of the 1980s, a number of events triggered increased scrutiny by journalists and regulators alike. In the pre-IPO market, investors bought when-issued shares at prices that were much higher than the offer price and the first-day closing price; this discrepancy led to suspicions that a small circle of speculators had driven up prices to artificially high levels (Elsevier 2000). Difficulties also arose with a company that announced a stock split but did not carry it out, and with two companies that altered the nominal value of the to-be-issued securities after when-issued trading had started (NRC Handelsblad 1988).

In January 1989, the Amsterdam Stock Exchange announced that it would from then on only allow when-issued trading under the following conditions: (i) whenissued trading prior to IPOs could only start after the prospectus had been published; (ii) brokers could only set up a market for post-split shares after an official announcement of the split had been made; and (iii) the 'Officiële Prijscourant', the official newspaper of the stock exchange, had to publish the prices of when-issued securities (NRC Handelsblad 1989).

However, already in 1992 the same exchange decided to prohibit pre-IPO trading, arguing that when-issued trading favors institutional investors, who often have more 
information than small traders (Algemeen Dagblad 1992). After 1992, pre-IPO whenissued trading only took place in some exceptional cases in which the firm itself had requested permission. ${ }^{2}$

In contrast, when-issued trading prior to stock splits became a common phenomenon. Therefore, in what follows, we will focus on when-issued trading prior to stock splits. By the end of 1998, however, the Amsterdam Stock Exchange decided to also ban pre-split grey markets. According to interviews with Euronext executives, this decision was taken because the trades could potentially "distort the market", for example when the positions built up in the when-issued market were growing too large or when delivery problems arose on the ex-date of the stock split.

\section{Related Literature on Stock Splits and When-Issued Trading}

Companies may split stocks for many reasons (Grinblatt et al. 1984; Lakonishok and Lev 1987; Angel 1997): to extend the shareholder base; to control the share price, the price span or the relative tick size; to call attention to the firm; or to signal bright future prospects. According to financial theory, however, the split of a stock is a costless nonevent - a purely cosmetic change - and should therefore have no effect on the value of a company (Lakonishok and Lev 1987; Lamoureux and Poon 1987). Nevertheless, two anomalies have formed the core of the stock split research for decades, namely the abnormal returns at different stages of the stock split process and the premiums paid for when-issued securities. In this paper, we concentrate on the issuance and the subsequent pricing of when-issued stocks.

Generally, when-issued markets have two unique features that need to be pointed out. First, there will only be when-issued trading when market makers, such as specialized brokers, have sufficient incentives to set up a grey market. Second, as the when-issued shares are not yet issued at the time of the transaction, trading always involves short-selling. The short-selling parties will have to make sure that they possess the relevant securities by the settlement date. Institutions face fewer restrictions on short-selling in the when-issued markets than retail investors, and therefore sellers in the when-issued market are more likely to be institutional investors, while buyers tend to be retail investors (Dorn 2009).

Figure 1 illustrates the timing of stock splits and when-issued trading. The stock split process starts with the official announcement of the planned split (date $\mathrm{T}_{A}$ ). When-issued trading mostly starts shortly after the announcement of the split, at time $\mathrm{T}_{W I}$. As from the record date $\left(\mathrm{T}_{R}\right)$, every old share will be accompanied by a due bill, or a certificate representing the split shares. If you own stocks on the record date, your shares will be subject to the stock split. Trading in when-issued shares normally continues until the evening before the effective date or ex-date $\left(\mathrm{T}_{0}\right)$. From this day onwards, only split shares are traded. The settlement of the when-issued shares takes place on $\mathrm{T}_{S}$, on or shortly after the ex-date.

\footnotetext{
2 Over the period 1989-1998, we record 13 cases of pre-IPO markets, with on average about a week of trading. The prices paid for these when-issued securities were in line with the first-day closing prices of the regular shares. After 1998, institutional investors and specialized brokers continued some pre-IPO trading outside the Netherlands, mainly in London (NRC Handelsblad 2000).
} 


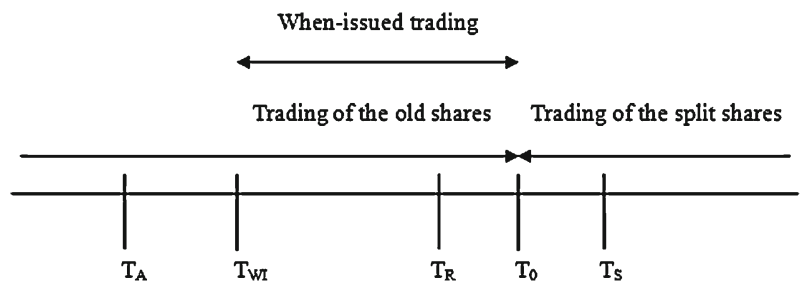

Fig. 1 When-issued trading prior to stock split. This figure shows the timing of events when there is whenissued trading prior to a stock split. Date $\mathrm{T}_{A}$ is the official announcement date of the split. When-issued trading starts at time $\mathrm{T}_{W I} . \mathrm{T}_{R}$ is the record date. Trading in when-issued shares can continue until ex-date $\mathrm{T}_{0}$. The settlement of the when-issued shares takes place at date $\mathrm{T}_{S}$

As explained before, even in regulatory environments where when-issued trading is endorsed, not every stock split announcement is followed by the organization of a when-issued market. Nayar and Rozeff (2001) argue that market makers will only organize a when-issued market when the potential number of trades is high and the costs are low. They further note that the potential number of trades in the when-issued share probably correlates positively with the trading volume of the unsplit stock. Similarly, Kemerer (2003) found that a when-issued market is more likely to be set up when the firm is larger. It is arguably harder to proxy for the expected costs of setting up a when-issued market. Yet, Nayar and Rozeff (2001) argue that these costs are likely to be higher for stocks with greater return volatilies, for two reasons. First, high variance may be caused by a high degree of informed trading in the stock, and "market makers prefer not to trade against informed traders" (p. 123). Second, high volatility can proxy for low liquidity, and market makers also avoid trading in illiquid stocks.

Most research on when-issued trading has focused on the so-called "when-issued premium". Choi and Strong (1983) were the first to note that when-issued shares violate the law of one price; in their sample, they trade at a premium of more than one percent over the regular unsplit shares. However, this raw premium has to be corrected for the time value of money: even though the contract is agreed upon during the when-issued trading period, the settlement only takes places after the actual issue. Buying the when-issued shares is thus "analogous to buying the stock on 100 percent margin with no interest charged on the debit balance" (Choi and Strong 1983, p. 1294). Yet the authors find that the premium persists after correcting the premium for this time value (and for the timing difference in the settlement procedure of when-issued shares relative to the old shares). Subsequent research has confirmed that, at least when using closing prices, when-issued shares indeed trade at a significant premium relative to regular shares in the U.S, even after the just-described adjustment. For example, Lamoureux and Wansley (1989) present a mean when-issued premium of $0.70 \%$ during the thirty-three trading days before the ex-date. Brooks and Chiou (1995) report an average proportional difference of $1.24 \%$ over the twenty trading days before the split. Nayar and Rozeff (2001) calculate an average premium of $1.93 \%$ over an interval of ten days around the record date of the stock split.

However, some of these studies have also argued that the adjusted premium should be further corrected for the non-synchronous nature of the pricing information and for bid-ask clustering. The first issue relates to the choice of benchmarks to calculate the premiums. Instead of only using closing stock prices, Lamoureux and Wansley (1989) 
also consider the daily high and low prices. The resulting premiums differ significantly from the premiums based on closing prices. Using intraday data, Brooks and Chiou (1995) match the trades by time of the day, which significantly reduces the premium reported before. Therefore, also the current paper will consider intraday high and low prices. Second, the premium can also be influenced by clustering at the bid or ask quote. Lamoureux and Wansley (1989) show that, if when-issued trades take place at the bid price or at the average of the bid and the ask price, the premium disappears. However, in their sample, most orders in the when-issued market are buys at the ask price, such that the premium is positive and different from zero. This form of clustering explains a large part of the premium in the paper by Brooks and Chiou (1995). The remaining part of the premium in their study results from the high number of buys relative to the number of sales. Unfortunately, our own data set does not contain information on bids and asks.

An underlying issue is to which degree when-issued markets contribute to market efficiency or liquidity. In the U.S., the NYSE allows when-issued trading because "the Exchange considers it desirable from the standpoint of public interest to afford shareholders (...) the facilities of the Exchange market for their shares at the earliest possible moment" (Lamoureux and Wansley 1989, p. 183). When-issued trading may also alleviate the inconveniences of trading in unsplit shares past the record date (Nayar and Rozeff 2001) or of receiving odd lot shares in the case of non-integer splits (Brooks and Chiou 1995). Angel et al. (2004) point out that when-issued shares may attract small-volume traders; as such, they may increase liquidity in the market already before the effective split date.

\section{Data}

To construct our sample, we started with all stock splits of firms listed on the Amsterdam Stock Exchange from 1989 until 1998, after which pre-split when-issued trading was prohibited. As is common in the literature, we excluded investment funds, reverse stock splits, and stock splits with a split factor smaller than 1.25. We also excluded two cases with insufficient data. This resulted in a total of 108 stock splits. Regular stock price information for these shares was retrieved from Datastream, and information on the announcement dates of the stock splits was collected using Lexis Nexis.

Unfortunately (though not surprisingly), data on when-issued transactions prior to stock splits are not electronically available. Since the beginning of 1989, the official newspaper of the Amsterdam Exchange, the 'Officiële Prijscourant', contains a separate section devoted to trading on a when-issued basis. We manually collected daily pricing data (low, high and closing prices) of the when-issued shares reported in the 'Officiële Prijscourant'. The records of the 'Officiële Prijscourant', indicate that when-issued trading occurred prior to 50 of the 108 observed splits. When-issued trading usually begins shortly after the announcement of the split. The median period of when-issued trading is slightly longer than 50 trading days.

Figure 2 shows the distribution of stock splits per year, partitioned in those with and those without when-issued trading. Based on the figure, two observations can be made. First, there was a particularly large number of stock splits in 1997. Second, 


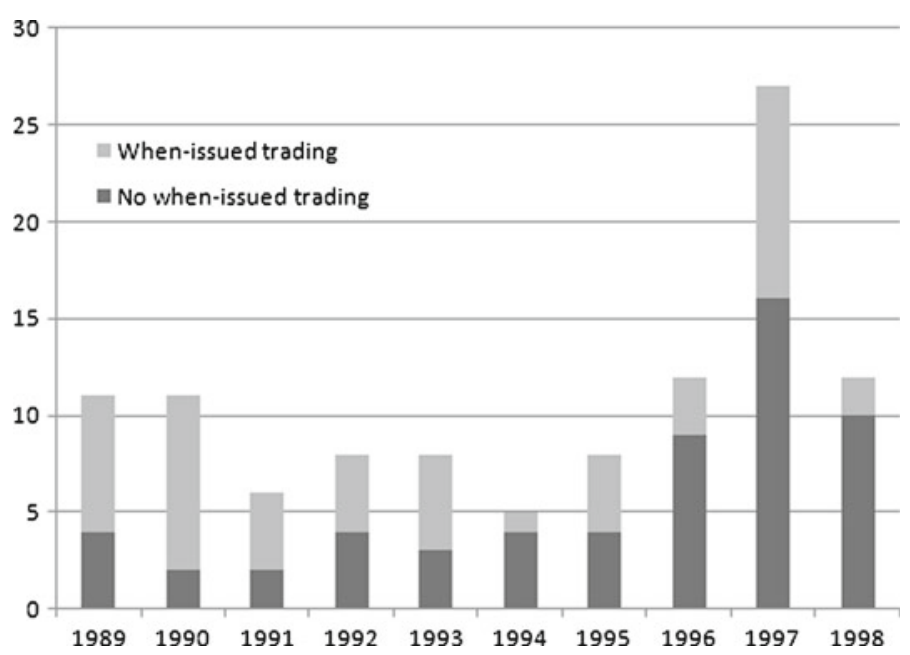

Fig. 2 Distribution of stock splits over time. This figure shows the number of stocks splits in our sample per year for the period 1989-1998, partitioned in those splits prior to which when-issued trading took place and the splits prior to which no when-issued trading occurred

there was relatively more when-issued trading prior to stock splits in the first years of our time frame.

\section{Empirical Results}

\subsection{What Explains the Creation of a When-Issued Market Prior to a Stock Split?}

We first want to investigate which factors explain the emergence of a when-issued market. The relevant dependent variable is a dummy variable equaling one when the announcement of the stock split is followed by the creation of a when-issued market. This is the case in 50 out of our 108 stock splits. When no when-issued market is set up, the dummy variable takes the value zero. We include the following split- and firm-related explanatory variables: the split ratio; the natural logarithm of the market capitalization (in real terms) on the trading day before the announcement date ${ }^{3}$ the average daily relative trading volume (measured as the total trading volume divided by number of outstanding shares) in the 100 trading days before the announcement date; the average daily market-adjusted stock return in the 100 trading days before the announcement date; the average daily standard deviation of this stock return in the 100 trading days before the announcement date.

The split ratio is important as a larger split ratio could indicate the firm's intention to attract more small-value investors, which may increase the probability that a

\footnotetext{
3 If the announcement date on Lexis Nexis falls after the start of the when-issued market, we replace the announcement date by this earlier date. If we cannot find an announcement date, we use the date of the first when-issued quotation (when a when-issued market is set up) or the date 50 trading days before the ex-date (when no when-issued trading takes place) as an approximation of the announcement date.
} 
Table 1 Descriptive statistics of the explanatory variables

\begin{tabular}{llllllr}
\hline Variable & N & Mean & SD & Min. & Median & Max. \\
\hline Split ratio & 108 & 5.48 & 5.63 & 1.92 & 4.00 & 50.00 \\
Ln(market cap) & 108 & 5.69 & 2.11 & 0.36 & 5.57 & 11.16 \\
Past volume & 108 & $3.65 \%$ & $5.00 \%$ & $0.00 \%$ & $1.66 \%$ & $35.67 \%$ \\
Past return & 108 & $0.06 \%$ & $0.17 \%$ & $-0.31 \%$ & $0.05 \%$ & $0.66 \%$ \\
Past volatility & 108 & $0.14 \%$ & $0.06 \%$ & $0.05 \%$ & $0.13 \%$ & $0.38 \%$ \\
\hline
\end{tabular}

This table reports the number of observations, the mean value, the standard deviation, the minimum value, the median value, and the maximum value of our main independent variables for the stock splits in our sample. Split ratio indicates in how many new shares the old share is split. Ln(market cap) is the natural logarithm of the market capitalization on the trading day before the announcement date. Past volume is the average daily trading volume, scaled by the number of outstanding shares, in the 100 trading days before the announcement date. Past return and Past volatility are the average daily market-adjusted stock return and the standard deviation of this daily return measured over the 100 trading days before the announcement date

when-issued market will be created. The variables measuring the market capitalization and the relative trading volume proxy for the potential profits for the market makers. Indeed, when a large firm or a firm with a relatively liquid stock splits its shares, it may be attractive to set up a when-issued market. On the contrary, we conjecture a negative relation between the standard deviation of the stock's daily return and our when-issued dummy variable. As explained before, Nayar and Rozeff (2001) argue that high return variance proxies for high expected costs for market makers. Finally, we also want to control for the impact of the stock return itself, although it is ex ante unclear how this would influence market makers' decisions. Table 1 gives an overview of the descriptive statistics of these variables.

In a first step we use a $t$ test to measure if there are significant differences in these variables between the group of stock splits without when-issued trading and the splits with when-issued trading. The results of these tests can be found in Table 2. Apparently, a when-issued market is set up for larger firms with higher relative trading volumes and less volatile stocks. These statistically significant results are in line with our expectations. There are no significant differences in the split ratio-although the average ratio is slightly higher for when-issued firms-or the average stock return. ${ }^{4}$

Second, we run a logit regression on our sample of 108 stock splits, in which we include all the above measures as independent variables. ${ }^{5}$ Our baseline regression results are shown in column (1) of Table 3 . To calculate the significance levels, we employ robust standard errors clustered by year to control for unobserved temporal heterogeneity. To make the regression results easily interpretable, we do not report the coefficients, but the resulting marginal effects at the averages of the independent variables.

\footnotetext{
4 The findings are robust to using a non-parametric Wilcoxon rank-sum test instead of a $t$ test (not reported).

5 We also experimented with a number of alternative estimation techniques, such as a linear probability model and a probit model, but this led to very similar results (not reported).
} 
Table 2 Differences between the two types of stock splits

\begin{tabular}{lllc}
\hline Variable & $\begin{array}{l}\text { No when-issued trading } \\
\text { Mean }(N=58)\end{array}$ & $\begin{array}{l}\text { When-issued trading } \\
\text { Mean }(N=50)\end{array}$ & $\begin{array}{l}\text { Difference in means } \\
t \text {-stat }\end{array}$ \\
\hline Split ratio & 5.33 & 5.66 & 0.31 \\
Ln(market cap) & 5.29 & 6.15 & $2.15^{* *}$ \\
Past volume & $2.86 \%$ & $4.56 \%$ & $1.77^{*}$ \\
Past return & $0.07 \%$ & $0.06 \%$ & -0.27 \\
Past volatility & $1.57 \%$ & $1.29 \%$ & $-2.49^{* *}$ \\
\hline
\end{tabular}

This table reports the results of a two-tailed $t$ test to identify significant differences between the means of the independent variables in the sample of stock splits with no prior when-issued trading and in the group of stock splits preceded by when-issued trading. All variables are defined in Table 1. *, **, and *** denote significance at the $10 \%, 5 \%$, and $1 \%$ level

Table 3 Regression results for the creation of when-issued markets

\begin{tabular}{llll}
\hline Variable & $(1)$ & $(2)$ & $(3)$ \\
\hline Split ratio & 0.01 & 0.01 & 0.00 \\
Ln(market cap) & $0.06^{\wedge}$ & $0.11^{* * *}$ & $0.12^{* * *}$ \\
Past volume & $3.13^{* * *}$ & $2.63 * *$ & $2.13^{\wedge}$ \\
Past return & -32.54 & -28.75 & -36.98 \\
Past volatility & $-221.59 * * *$ & $-91.51^{*}$ & -57.97 \\
Interest & & $8.99 * * *$ & 3.21 \\
Time trend & & & -0.06 \\
Constant & incl. & incl. & incl. \\
N & 108 & 108 & 108 \\
Pseudo R-squared & 0.11 & 0.19 & 0.21 \\
\hline
\end{tabular}

This table summarizes the logit regression results of three models explaining the creation of when-issued markets. The dependent variable is a dummy variable indicating whether a when-issued market is set up prior to a stock split (one) or not (zero). We report the marginal effects calculated at the average of the relevant independent variable. All variables are defined below Table 1, except Interest, which is the 1-month Amsterdam Interbank Offer Rate in the quarter of the announcement date, and Time trend, which is based on the year of the split. Robust standard errors clustered by year are used to calculate significance levels. $\hat{n}, * * *$, and $* * *$ denote significance at the $15 \%, 10 \%, 5 \%$, and $1 \%$ level

The results confirm that stock splits of firms with a higher market capitalization ( $p$ value of 0.11 ) and high relative trading volume are significantly more likely to be preceded by when-issued trading. In line with our expectations, a high standard deviation in the stock returns has a negative effect on the creation of when issued markets. We do not find a significant relation between when-issued trading on the one hand, and the split ratio and the past stock return on the other.

Apart from the statistical significance, it is also important to examine the economic significance of the results. Based on the coefficients in column (1), we infer that if we increase the natural logarithm of the market capitalization with one standard deviation from its average, the estimated change in the response probability is $12.50 \%$ (assuming constant marginal effects over the independent variable for simplicity). Similarly, 
if the relative volume and the volatility of the abnormal returns increases by one standard deviation, the estimated probability of the emergence of a when-issued market increases by $15.63 \%$ and decreases by $13.14 \%$, respectively.

In column (2), we repeat the regression including an extra explanatory variable, namely the quarterly money market interest rate (1-month Amsterdam Interbank Offer Rate) in the quarter of the announcement date. These data are obtained from the Dutch central bank. Since a transaction in the when-issued market is essentially a forward contract, it may be that market makers are more interested in creating when-issued markets when interest rates are high. The results for the interest rate are strongly significant, which could signify that when-issued markets are indeed more likely to be set up in periods of high interest rates. However, we cannot exclude the possibility that this variable is merely capturing a time effect in the demand for when-issued trading, as the interest rate broadly decreases throughout our whole time period. Therefore, in column (3) we also include a time trend. We see that the coefficient on the interest rate variable is no longer significantly positive. ${ }^{6}$

\subsection{The When-Issued Premium}

We now want to test whether when-issued securities trade at a premium during the period of simultaneous trading in the official and when-issued market. The whenissued premium (not adjusted for the time value of money) can be calculated as the proportional difference between the price of the when-issued security (adjusted for the split factor) and the price of a regular share:

\section{when-issued premium $=($ when-issued price - regular price $) /$ regular price}

We calculate the average when-issued premium for each of the 50 trading days prior to the ex-date of the stock split-going from T-50 to T-1 (the trading day before the actual split)—based on the when-issued and regular share prices. We do not merely analyze the closing prices, but also consider the intraday low and high prices. We do this because possible violations of the law of one price may result from improper measurement such as non-synchronous trading in the two types of securities (Ezzell et al. 2003). As Lamoureux and Wansley (1989, p. 187) note: "Although the use of high and low prices, in addition to the closing prices will not eliminate any possible bias caused by non-synchronous trading, the comparison should indicate if non-synchronous trading is a likely source of the premium."

Table 4 shows the average premiums for each trading day, based on closing prices and on intraday low and high prices. When we use the closing prices, we find positive premiums for each trading day, except for day T-2. The premium is significantly different from zero on most trading days, broadly ranging in value between $0.50 \%$ and $1.50 \%$, but not in the 4 days prior to the split. Indeed, in the last few trading days, the premium is close to zero. This finding is in line with previous work.

\footnotetext{
6 In contrast, we still see that when-issued markets are more likely to be set up when the expected number of trades is high. The coefficient on the volatility variable loses significance but still has the expected sign.
} 
Table 4 Premiums (not adjusted)

\begin{tabular}{|c|c|c|c|c|c|c|c|}
\hline \multirow[t]{2}{*}{ Date } & \multirow[t]{2}{*}{$\mathrm{N}$} & \multicolumn{2}{|c|}{ Closing prices } & \multicolumn{2}{|c|}{ Intraday low prices } & \multicolumn{2}{|c|}{ Intraday high prices } \\
\hline & & Mean $(\%)$ & $\%$ pos. & Mean $(\%)$ & $\%$ pos. & Mean $(\%)$ & $\%$ pos. \\
\hline $\mathrm{T}-50$ & 17 & $0.93 *$ & 76.47 & $1.20 * * *$ & 82.35 & 0.68 & 70.59 \\
\hline $\mathrm{T}-49$ & 22 & 0.66 & 68.18 & $1.13 * *$ & 72.73 & 0.46 & 68.18 \\
\hline $\mathrm{T}-48$ & 20 & $1.05^{* *}$ & 75.00 & $1.15^{* *}$ & 75.00 & $0.85 *$ & 70.00 \\
\hline $\mathrm{T}-47$ & 22 & $0.85^{*}$ & 63.64 & $1.35 * * *$ & 77.27 & 0.90 & 68.18 \\
\hline $\mathrm{T}-46$ & 20 & $1.21 * * *$ & 75.00 & $1.29 * * *$ & 75.00 & $0.99 * *$ & 75.00 \\
\hline $\mathrm{T}-45$ & 23 & $0.82 * *$ & 69.57 & $1.29 * * *$ & 73.91 & $0.84 * *$ & 69.57 \\
\hline $\mathrm{T}-44$ & 23 & $0.96^{*}$ & 69.57 & $1.07 * *$ & 73.91 & 0.83 & 69.57 \\
\hline $\mathrm{T}-43$ & 22 & 0.64 & 63.64 & $0.95 * *$ & 77.27 & 0.55 & 63.64 \\
\hline $\mathrm{T}-42$ & 24 & 0.73 & 66.67 & $1.02 * *$ & 70.83 & 0.63 & 58.33 \\
\hline $\mathrm{T}-41$ & 26 & $0.79 *$ & 65.38 & $0.94 * *$ & 69.23 & 0.64 & 61.54 \\
\hline $\mathrm{T}-40$ & 24 & $0.92 * *$ & 66.67 & $0.91 * *$ & 66.67 & 0.57 & 54.17 \\
\hline Т-39 & 26 & $0.74 *$ & 65.38 & $1.06 * *$ & 76.92 & $0.85 *$ & 65.38 \\
\hline T-38 & 25 & $1.10 *$ & 52.00 & $0.89 *$ & 72.00 & 0.80 & 56.00 \\
\hline $\mathrm{T}-37$ & 26 & $1.34 * * *$ & 73.08 & $1.44 * * *$ & 73.08 & $1.22 * *$ & 69.23 \\
\hline $\mathrm{T}-36$ & 27 & $1.22 * *$ & 74.07 & $1.53 * *$ & 74.07 & $1.10 * *$ & 70.37 \\
\hline $\mathrm{T}-35$ & 26 & $0.93 *$ & 61.54 & $1.16^{* *}$ & 65.38 & 0.79 & 61.54 \\
\hline $\mathrm{T}-34$ & 24 & 0.73 & 66.67 & $1.04 *$ & 70.83 & 0.61 & 62.50 \\
\hline $\mathrm{T}-33$ & 30 & $0.94 *$ & 63.33 & 0.83 & 63.33 & 0.76 & 60.00 \\
\hline $\mathrm{T}-32$ & 30 & 0.84 & 66.67 & $1.13 * *$ & 70.00 & $0.83 *$ & 60.00 \\
\hline $\mathrm{T}-31$ & 30 & $0.89 *$ & 63.33 & $1.17 * *$ & 66.67 & 0.64 & 63.33 \\
\hline $\mathrm{T}-30$ & 30 & $0.92 * *$ & 76.67 & $1.00 * *$ & 73.33 & 0.61 & 60.00 \\
\hline $\mathrm{T}-29$ & 29 & 0.51 & 68.97 & $0.71 *$ & 68.97 & 0.46 & 62.07 \\
\hline $\mathrm{T}-28$ & 30 & $0.62 *$ & 66.67 & $0.73 * *$ & 73.33 & 0.38 & 60.00 \\
\hline $\mathrm{T}-27$ & 31 & $0.93 * *$ & 74.19 & $1.23 * * *$ & 80.65 & 0.50 & 67.74 \\
\hline $\mathrm{T}-26$ & 32 & $0.98 * * * *$ & 81.25 & $1.00 * * *$ & 81.25 & $0.70 * *$ & 68.75 \\
\hline $\mathrm{T}-25$ & 32 & 0.53 & 68.75 & $0.83 * *$ & 75.00 & 0.47 & 68.75 \\
\hline $\mathrm{T}-24$ & 30 & $0.82 * *$ & 73.33 & $1.00 * * *$ & 83.33 & 0.40 & 73.33 \\
\hline $\mathrm{T}-23$ & 33 & $0.81^{* *}$ & 66.67 & $0.92 * * *$ & 75.76 & 0.62 & 69.70 \\
\hline $\mathrm{T}-22$ & 31 & $0.59 *$ & 61.29 & $0.87 * *$ & 74.19 & 0.46 & 58.06 \\
\hline $\mathrm{T}-21$ & 32 & $0.65^{* *}$ & 71.88 & $0.99 * *$ & 78.13 & 0.49 & 65.63 \\
\hline $\mathrm{T}-20$ & 30 & $0.79 * *$ & 70.00 & $1.05 * * *$ & 76.67 & $0.71 * *$ & 63.33 \\
\hline T-19 & 29 & $1.14 * * *$ & 68.97 & $1.25 * * *$ & 82.76 & $0.95 * * *$ & 65.52 \\
\hline T-18 & 31 & 1.10 **** & 87.10 & $1.42 * * *$ & 93.55 & $1.13 * * *$ & 77.42 \\
\hline $\mathrm{T}-17$ & 29 & 0.65 & 72.41 & $0.90 * *$ & 82.76 & $0.66^{*}$ & 79.31 \\
\hline $\mathrm{T}-16$ & 30 & $1.20 * * *$ & 80.00 & $1.78 * * *$ & 86.67 & $0.86^{* * *}$ & 80.00 \\
\hline $\mathrm{T}-15$ & 30 & $1.49 * * *$ & 86.67 & $1.65 * * *$ & 90.00 & $1.31 * * *$ & 80.00 \\
\hline $\mathrm{T}-14$ & 30 & $0.88 * * *$ & 73.33 & $1.06 * * *$ & 80.00 & $0.72 * * *$ & 70.00 \\
\hline $\mathrm{T}-13$ & 31 & $1.17 * * *$ & 87.10 & $1.29 * * *$ & 83.87 & $0.99 * * *$ & 77.42 \\
\hline $\mathrm{T}-12$ & 31 & $0.91 * * *$ & 70.97 & $1.31 * * *$ & 87.10 & $0.55 * *$ & 64.52 \\
\hline
\end{tabular}


Table 4 continued

\begin{tabular}{|c|c|c|c|c|c|c|c|}
\hline \multirow[t]{2}{*}{ Date } & \multirow[t]{2}{*}{$\mathrm{N}$} & \multicolumn{2}{|c|}{ Closing prices } & \multicolumn{2}{|c|}{ Intraday low prices } & \multicolumn{2}{|c|}{ Intraday high prices } \\
\hline & & Mean (\%) & $\%$ pos. & Mean $(\%)$ & $\%$ pos. & Mean $(\%)$ & $\%$ pos. \\
\hline $\mathrm{T}-11$ & 31 & $0.60 * *$ & 74.19 & $0.87 * * *$ & 77.42 & $0.49 *$ & 74.19 \\
\hline $\mathrm{T}-10$ & 35 & $0.94 * * *$ & 80.00 & $1.32 * * *$ & 88.57 & $0.65 * *$ & 71.43 \\
\hline $\mathrm{T}-9$ & 36 & $0.64 * * *$ & 72.22 & $0.96 * * *$ & 88.89 & $0.41 *$ & 63.89 \\
\hline $\mathrm{T}-8$ & 36 & $0.96 * * *$ & 75.00 & $1.02 * * *$ & 88.89 & $0.58 * *$ & 63.89 \\
\hline $\mathrm{T}-7$ & 33 & $0.82 * * *$ & 72.73 & $0.84 * * *$ & 78.79 & $0.65 * *$ & 66.67 \\
\hline $\mathrm{T}-6$ & 32 & $0.90 * * *$ & 65.63 & $1.30 * * *$ & 87.50 & $0.79 * *$ & 71.88 \\
\hline $\mathrm{T}-5$ & 32 & $0.49 * *$ & 68.75 & $0.65 * *$ & 81.25 & $0.48^{*}$ & 56.25 \\
\hline $\mathrm{T}-4$ & 36 & 0.28 & 55.56 & 0.30 & 63.89 & 0.21 & 50.00 \\
\hline $\mathrm{T}-3$ & 34 & 0.22 & 52.94 & $0.63 * * *$ & 73.53 & 0.42 & 55.88 \\
\hline $\mathrm{T}-2$ & 32 & -0.10 & 46.88 & 0.30 & 75.00 & 0.10 & 34.38 \\
\hline $\mathrm{T}-1$ & 31 & 0.10 & 48.39 & 0.07 & 58.06 & 0.10 & 51.61 \\
\hline
\end{tabular}

This table reports the mean when-issued premiums, not adjusted for the time value of money, for all trading days from T-50 (50 trading days prior to the split) to T-1. The premiums are calculated using the closing prices and the intraday low and high prices of the regular shares and the when-issued securities. *, **, and $* * *$ denote significance at the $10 \%, 5 \%$, and $1 \%$ level. The table also reports the proportion of positive premiums in each case

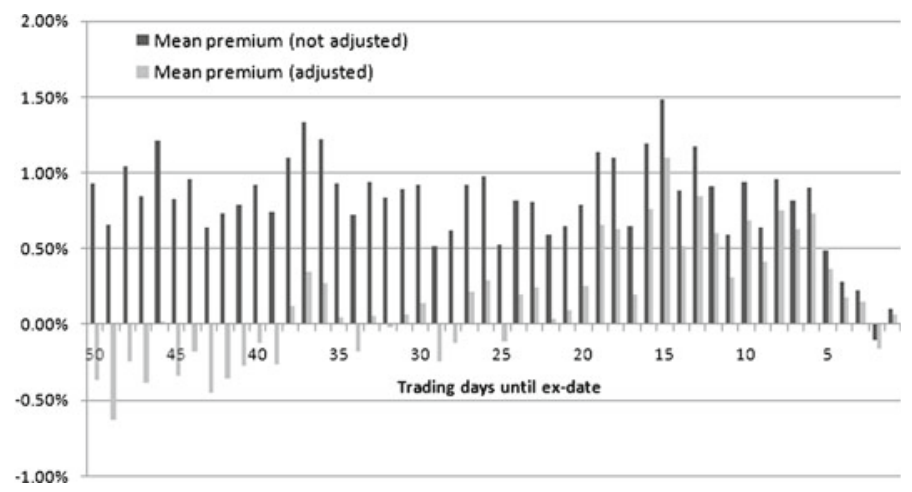

Fig. 3 Average daily when-issued premiums based on closing prices. This figures shows the average whenissued premiums, both before and after adjustment for the time value of money, for all trading days from 50 trading days to one trading day before the split. The premiums are calculated using the closing prices of the regular shares and the when-issued securities. The underlying data can be found in Tables 4 and 5

Choi and Strong (1983, p. 1296) had already noted "a slight decline during the time close to the distribution date". In the study by Lamoureux and Wansley (1989), the premium during the last when-issued trading days was also much smaller than the one observed the weeks before. The average closing-price premiums are also graphically depicted in Fig. 3.

When we calculate the premiums on the basis of the intraday low or high prices, we arrive at a similar picture, although the use the low (resp. high) prices leads to bigger (resp. smaller) premiums. This is in line with the results of Lamoureux and Wansley (1989) and may result from price rigidity in the when-issued market: there are only a 
limited number of quotations per day and therefore when-issued prices tend to fluctuate less. Nevertheless, the when-issued premium is still often statistically significant even when the intraday high prices are used to measure the premium.

Table 4 also shows the proportion of when-issued premiums that are positive for each trading day. On almost all days, the proportion of shares trading at a premium is clearly above $50 \%$, no matter what price information is used. Again, we observe a significant decline in the last trading days.

\subsection{Adjusting the When-Issued Premium for the Time Value of Money}

Transactions involving when-issued shares are always conditional on the actual issue. Therefore, the settlement of the when-issued securities only takes place along with the transactions done on the ex-date of the stock split. We now investigate to what extent the time value of money accounts for the observed premiums and we adjust the prices of the when-issued securities as follows:

$$
\text { adjusted when-issued price }=\text { when-issued price } *(1+r)^{-\tau / 365} \text {, }
$$

where $r$ is the relevant annual loan rate and $\tau$ is the number of calendar days left until the effective date. Using the 1-month Amsterdam Interbank Offer Rate presented before, we recalculate our premiums as follows:

$$
\begin{aligned}
& \text { adjusted when-issued premium } \\
& \quad=(\text { adjusted when-issued price-regular price }) / \text { regular price. }
\end{aligned}
$$

The results of the analysis can be found in Table 5 where we report similar statistics as in Table 4. The difference between the premiums in Tables 4 and 5 is striking. Considering the premiums calculated on the basis of the closing prices, we observe that there is no premium prior to T-19 that is significantly different from zero. Whenissued securities even seem to trade at a discount - rather than at a premium-in the first third of our time frame, although those results are not statistically significant at the $10 \%$ level.

There still is a significant positive when-issued premium on various trading days in the period four weeks to one week prior to the stock split. In this period, the premium is about $0.60 \%$ on average, which is low compared to earlier U.S. studies. Whether the premium was high enough to instigate profitable arbitrage strategies is unclearprobably only large institutional investors or brokers have sufficiently low transactions costs to benefit. Again, it is remarkable that the adjusted premium is virtually zero in the last week before the stock split takes place. The fluctuations through time in the adjusted premiums based on the closing prices is also shown in Fig. 3.

We conclude that the adjustment for the time value of money erodes the when-issued premium. However, even after adjusting for the time value of money, we still observe violations of the law of one price in the last month prior to the ex-date. As pointed out in the previous subsection, the premium is higher when we use the intraday low prices and is lower when we consider the high intraday prices. The data availability does not enable us to check whether the adjusted premium can be further explained by bid-ask clustering or by the relative frequency of purchases/sales. Whereas previous studies 
Table 5 Premiums (adjusted)

\begin{tabular}{|c|c|c|c|c|c|c|c|}
\hline \multirow[t]{2}{*}{ Date } & \multirow[t]{2}{*}{$\mathrm{N}$} & \multicolumn{2}{|c|}{ Closing prices } & \multicolumn{2}{|c|}{ Intraday low prices } & \multicolumn{2}{|c|}{ Intraday high prices } \\
\hline & & Mean $(\%)$ & $\%$ pos. & Mean $(\%)$ & $\%$ pos. & Mean (\%) & $\%$ pos. \\
\hline $\mathrm{T}-50$ & 17 & -0.37 & 41.18 & -0.10 & 41.18 & -0.62 & 35.29 \\
\hline $\mathrm{T}-49$ & 22 & -0.63 & 27.27 & -0.16 & 45.45 & $-0.83 * *$ & 36.36 \\
\hline $\mathrm{T}-48$ & 20 & -0.24 & 35.00 & -0.14 & 35.00 & -0.43 & 30.00 \\
\hline $\mathrm{T}-47$ & 22 & -0.39 & 31.82 & 0.10 & 40.91 & -0.34 & 31.82 \\
\hline $\mathrm{T}-46$ & 20 & 0.02 & 55.00 & 0.10 & 55.00 & -0.21 & 50.00 \\
\hline $\mathrm{T}-45$ & 23 & -0.34 & 39.13 & 0.12 & 60.87 & -0.32 & 34.78 \\
\hline $\mathrm{T}-44$ & 23 & -0.17 & 34.78 & -0.06 & 47.83 & -0.30 & 39.13 \\
\hline $\mathrm{T}-43$ & 22 & -0.45 & 40.91 & -0.14 & 45.45 & -0.54 & 36.36 \\
\hline $\mathrm{T}-42$ & 24 & -0.36 & 45.83 & -0.07 & 37.50 & -0.45 & 41.67 \\
\hline $\mathrm{T}-41$ & 26 & -0.27 & 38.46 & -0.12 & 38.46 & -0.42 & 34.62 \\
\hline $\mathrm{T}-40$ & 24 & -0.12 & 45.83 & -0.13 & 45.83 & -0.46 & 37.50 \\
\hline $\mathrm{T}-39$ & 26 & -0.26 & 42.31 & 0.05 & 46.15 & -0.16 & 46.15 \\
\hline $\mathrm{T}-38$ & 25 & 0.13 & 40.00 & -0.08 & 40.00 & -0.17 & 32.00 \\
\hline $\mathrm{T}-37$ & 26 & 0.35 & 53.85 & 0.45 & 53.85 & 0.24 & 53.85 \\
\hline $\mathrm{T}-36$ & 27 & 0.27 & 44.44 & 0.57 & 48.15 & 0.15 & 44.44 \\
\hline $\mathrm{T}-35$ & 26 & 0.05 & 46.15 & 0.28 & 53.85 & -0.09 & 42.31 \\
\hline $\mathrm{T}-34$ & 24 & -0.18 & 37.50 & 0.13 & 37.50 & -0.30 & 37.50 \\
\hline $\mathrm{T}-33$ & 30 & 0.06 & 50.00 & -0.05 & 43.33 & -0.12 & 50.00 \\
\hline $\mathrm{T}-32$ & 30 & -0.02 & 43.33 & 0.27 & 50.00 & -0.03 & 46.67 \\
\hline $\mathrm{T}-31$ & 30 & 0.06 & 56.67 & 0.34 & 53.33 & -0.19 & 50.00 \\
\hline $\mathrm{T}-30$ & 30 & 0.14 & 50.00 & 0.21 & 46.67 & -0.17 & 46.67 \\
\hline $\mathrm{T}-29$ & 29 & -0.24 & 41.38 & -0.04 & 41.38 & -0.29 & 41.38 \\
\hline $\mathrm{T}-28$ & 30 & -0.13 & 50.00 & -0.02 & 50.00 & -0.36 & 40.00 \\
\hline $\mathrm{T}-27$ & 31 & 0.21 & 61.29 & 0.52 & 67.74 & -0.21 & 51.61 \\
\hline $\mathrm{T}-26$ & 32 & 0.29 & 65.63 & 0.32 & 56.25 & 0.01 & 53.13 \\
\hline $\mathrm{T}-25$ & 32 & -0.12 & 46.88 & 0.18 & 53.13 & -0.18 & 50.00 \\
\hline $\mathrm{T}-24$ & 30 & 0.20 & 53.33 & 0.38 & 56.67 & -0.21 & 43.33 \\
\hline $\mathrm{T}-23$ & 33 & 0.24 & 54.55 & 0.35 & 51.52 & 0.05 & 51.52 \\
\hline $\mathrm{T}-22$ & 31 & 0.04 & 48.39 & 0.31 & 51.61 & -0.10 & 41.94 \\
\hline $\mathrm{T}-21$ & 32 & 0.10 & 53.13 & 0.44 & 59.38 & -0.06 & 46.88 \\
\hline $\mathrm{T}-20$ & 30 & 0.26 & 60.00 & 0.51 & 60.00 & 0.18 & 46.67 \\
\hline T-19 & 29 & $0.66^{*}$ & 55.17 & $0.77 * *$ & 65.52 & 0.47 & 44.83 \\
\hline $\mathrm{T}-18$ & 31 & 0.63 & 54.84 & $0.95^{* * *}$ & 67.74 & 0.65 & 54.84 \\
\hline $\mathrm{T}-17$ & 29 & 0.20 & 55.17 & 0.45 & 72.41 & 0.21 & 51.72 \\
\hline $\mathrm{T}-16$ & 30 & $0.76^{* *}$ & 63.33 & $1.34 * * *$ & 76.67 & 0.43 & 60.00 \\
\hline $\mathrm{T}-15$ & 30 & $1.10 * * *$ & 76.67 & $1.27 * * *$ & 73.33 & $0.92 * * *$ & 66.67 \\
\hline $\mathrm{T}-14$ & 30 & $0.52 * *$ & 50.00 & $0.70 * * *$ & 63.33 & 0.35 & 56.67 \\
\hline $\mathrm{T}-13$ & 31 & $0.85 * * *$ & 74.19 & $0.97 * * *$ & 77.42 & $0.66^{* *}$ & 70.97 \\
\hline $\mathrm{T}-12$ & 31 & $0.61 * *$ & 58.06 & $1.00 * * *$ & 77.42 & 0.25 & 58.06 \\
\hline
\end{tabular}


Table 5 continued

\begin{tabular}{|c|c|c|c|c|c|c|c|}
\hline \multirow[t]{2}{*}{ Date } & \multirow[t]{2}{*}{$\mathrm{N}$} & \multicolumn{2}{|c|}{ Closing prices } & \multicolumn{2}{|c|}{ Intraday low prices } & \multicolumn{2}{|c|}{ Intraday high prices } \\
\hline & & Mean $(\%)$ & $\%$ pos. & Mean $(\%)$ & $\%$ pos. & Mean $(\%)$ & $\%$ pos. \\
\hline $\mathrm{T}-11$ & 31 & 0.31 & 54.84 & $0.58 * *$ & 64.52 & 0.21 & 61.29 \\
\hline $\mathrm{T}-10$ & 35 & $0.69 * * *$ & 65.71 & $1.07 * * *$ & 80.00 & 0.39 & 65.71 \\
\hline $\mathrm{T}-9$ & 36 & $0.41 *$ & 69.44 & $0.73 * * *$ & 77.78 & 0.19 & 63.89 \\
\hline $\mathrm{T}-8$ & 36 & $0.75 * * *$ & 66.67 & $0.82 * * *$ & 75.00 & 0.38 & 58.33 \\
\hline $\mathrm{T}-7$ & 33 & $0.63 * *$ & 66.67 & $0.65^{* *}$ & 69.70 & 0.47 & 57.58 \\
\hline $\mathrm{T}-6$ & 32 & $0.74 * *$ & 56.25 & $1.13 * * *$ & 81.25 & $0.62 * *$ & 53.13 \\
\hline $\mathrm{T}-5$ & 32 & 0.36 & 50.00 & $0.53 * *$ & 59.38 & 0.36 & 50.00 \\
\hline $\mathrm{T}-4$ & 36 & 0.18 & 41.67 & 0.21 & 52.78 & 0.11 & 41.67 \\
\hline $\mathrm{T}-3$ & 34 & 0.15 & 47.06 & $0.55^{* *}$ & 73.53 & 0.34 & 47.06 \\
\hline $\mathrm{T}-2$ & 32 & -0.16 & 46.88 & 0.25 & 68.75 & 0.05 & 31.25 \\
\hline $\mathrm{T}-1$ & 31 & 0.06 & 48.39 & 0.04 & 54.84 & 0.07 & 48.39 \\
\hline
\end{tabular}

This table reports the average when-issued premiums, adjusted for the time value of money, for all trading days from T-50 (50 trading days prior to the split) to T-1. The premiums are calculated using the closing prices and the intraday low and high prices of the regular shares and the when-issued securities. *, **, and $* * *$ denote significance at the $10 \%, 5 \%$, and $1 \%$ level. The table also reports the proportion of positive premiums in each case

(Brooks and Chiou 1995; Ezzell et al. 2003) have used these factors to explain a part of a consistently positive when-issued premium, it is unlikely that these explanations would hold in our case as our adjusted premium evolves from slightly negative to significantly positive and then to zero. The hypothesis that it is inconvenient to trade in regular shares after the record date has no explanatory power either, since the record date traditionally falls the day before the ex-date in the Netherlands.

\section{Conclusions}

We investigate the grey market in the Netherlands over the 1989-1998 time frame. A when-issued market is organized prior to almost half of the stock splits that take place on the Amsterdam Stock Exchange, implying that there is a clear demand for such grey markets. Trading starts shortly after the official announcement of the split. We provide evidence that market makers are more likely to set up a when-issued market before a stock split when the number of expected trades is large and the expected costs are low, i.e. for large firms with liquid and not too volatile stocks.

When-issued securities trade at a small, but economically significant premium prior to a stock split. On the basis of when-issued and regular share closing prices, we calculate premiums of $0.50-1.50 \%$ on nearly all of the 50 trading days leading up to the stock split. When we correct the premium for the time value of money effect, the premium disappears until roughly 20 trading days before the split. After this date, and until a week prior to the effective date, the average premium is about $0.60 \%$. There is no premium in the last days before the stock split. It is not clear what could explain this wave-like pattern in adjusted when-issued premiums. We leave this for further research. 
Acknowledgments The authors would like to thank two anonymous referees for valuable comments and suggestions, and Euronext Amsterdam and Reza van Roosmalen for help with the data collection. Spaenjers thanks the Netherlands Organisation for Scientific Research (NWO) for financial support. All errors are ours.

Open Access This article is distributed under the terms of the Creative Commons Attribution Noncommercial License which permits any noncommercial use, distribution, and reproduction in any medium, provided the original author(s) and source are credited.

\section{References}

Algemeen Dagblad, A. (1992, October 27). Verbod op 'grijze handel' in OPG ["Ban on 'grey trade' in $O P G$ ”].

Angel, J. J. (1997). Tick size, share prices, and stock splits. Journal of Finance, 52, 655-681.

Angel, J. J., Brooks, R. M., \& Mathew, P. G. (2004). When-issued shares, small trades, and the variance of returns around stock splits. Journal of Financial Research, 27, 415-433.

Brooks, R. M., \& Chiou, S.-N. (1995). A bias in closing prices: The case of the when-issued pricing anomaly. Journal of Financial and Quantitative Analysis, 30, 441-454.

Choi, D., \& Strong, R. A. (1983). The pricing of when-issued common stock: A note. Journal of Finance, 38, 1293-1298.

Cornelli, F., Goldreich, D., \& Ljungqvist, A. (2006). Investor sentiment and pre-IPO markets. Journal of Finance, 61, 1187-1216.

De Volkskrant. (2000, March 9). Grijs shoppen ["Shopping grey"].

Dorn, D. (2009). Does sentiment drive the retail demand for IPOs? Journal of Financial and Quantitative Analysis, 44, 85-108.

Elsevier. (2000, March 18). In de grijze handel ["In the grey trade"].

Ezzell, J. R., Miles, J. A., \& Mulherin, J. H. (2003). Is there really a when-issued premium? Journal of Financial and Quantitative Analysis, 38, 611-634.

Grinblatt, M. S., Masulis, R. W., \& Titman, S. (1984). The valuation effects of stock splits and stock dividends. Journal of Financial Economics, 13, 461-490.

Kemerer, K. L., (2003). Differential reaction to stock split announcements: From a when-issued trading perspective. Unpublished working paper Florida Memorial College.

Lakonishok, J., \& Lev, B. (1987). Stock splits and stock dividends: Why, who, and when. The Journal of Finance, 42, 913-932.

Lamoureux, C. G., \& Poon, P. (1987). The market reaction to stock splits. The Journal of Finance, 42, $1347-1370$

Lamoureux, C. G., \& Wansley, J. W. (1989). The pricing of when-issued securities. The Financial Review, 24, 183-198.

Löffler, G., Panther, P. F., \& Theissen, E. (2005). Who knows what when? The information content of pre-IPO market prices. Journal of Financial Intermediation, 14, 466-484.

Loss, L., \& Vernon, R. (1945). When-issued securities trading in law and practice. The Yale Law Journal, 54, 741-798.

Nayar, N., \& Rozeff, M. S. (2001). Record date, when-issued, and ex-date effects in stock splits. Journal of Financial and Quantitative Analysis, 36, 119-139.

NRC Handelsblad. (1988, October 22). Spookhandel op beurs roept om regels ["Phantom trade on exchange asks for regulation"].

NRC Handelsblad. (1989, January 25). Beurs beperkt 'spookhandel' in aandelen ["Exchange limits 'phantom trade' in stocks"].

NRC Handelsblad. (2000, July 4). Reclameverbod bij beursgang is verkeerd signaal ["Ban on advertising around IPO is wrong signal"]. 